\title{
ARTICLE 8 OF THE CONVENTION FOR THE PROTECTION OF HUMAN RIGHTS AND FUNDAMENTAL FREEDOMS AND THE RIGHT TO PRIVACY IN THE CONSTITUTION OF MONTENEGRO
}

\begin{abstract}
International protection of human rights can be discussed only once international jurisdiction manages to impose itself and fit in with the national jurisdictions and when the transition is made from guarantees within the state, prevalent at present stage, to guarantees against the state.
\end{abstract}

(Bobio, 2008, p. 41)

\begin{abstract}
The subject of this paper is a comparative analysis of the right to respect for private and family life in the European Convention for the Protection of Human Rights and Fundamental Freedoms and the right to privacy in the Constitution of Montenegro. To this end, the paper presents relevant provisions in these documents along with a critical approach to their (in) compliance, both in the determination of specific rights and in cases of their restriction. The paper seeks to offer an answer to the question on whether this right is adequately implemented in the Constitution of Montenegro, as well as whether its different content, analyzed on the concrete example, requires direct application of international law. The author also seeks to provide information on whether insufficient harmonization of the provisions of international and national law in this area may affect more complete protection of this right. To this end, the paper analyzes one of the cases in which the European Court of Human Rights ruled on the violation of Article 8 of the European Convention for the Protection of Human Rights and Fundamental Freedoms in relation to Montenegro. Starting from the presented subject matter, at the end of the paper, appropriate conclusions are drawn about possible directions of improvement of existing solutions and practices in which they are realized. Author primarily used normative and comparative law method together with the case-law analysis.

Keywords: right to respect for private life, the Convention for the Protection of Human Rights and Fundamental Freedoms, the Constitution of Montenegro, court practice.
\end{abstract}

\footnotetext{
* Master of Law (MLS), Program director of the Center for Monitoring and Research (CeMI), Podgorica, Montenegro,e-mail: ivan.vukcevic@yahoo.com
} 


\section{Introduction}

The process of internationalization of human rights raises a number of questions on the relationship between international and domestic law. This is significant to the extent that special legal disciplines, such as International human rights law have developed out of the study of this relationship, or traditional disciplines (constitutional law, criminal law) have been substantially upgraded with new dimensions of human rights. These developments are particularly significant in the European legal area which with its ramification of institutions of protection of human rights, their design and practice, represent the most effective mechanisms for their protection at the international level. At the same time, it has influenced the expansion of the area of legal dialogue, which is important for relations arising in the process of applying the standards of the European Convention for the Protection of Human Rights and Fundamental Freedoms (hereinafter the Convention) and its impact on constitutional systems and case law of state signatories to the Convention. Consequently, it is important for the relationship between the European Court of Human Rights (hereinafter ECtHR) and national courts (constitutional and regular) on this issue, which are characterized by relations of approximation of the systems, their unification and homogenization, all in order to strengthen values and principles, which shape them (De Vergottini, 2015, p. 47).

Such legal, more precisely normative challenges, also apply to the consideration of the normative regulation of certain rights in the Convention and the constitutions of the signatory states, and the analysis of one of those rights (right to respect for private and family life, i.e. the right to privacy) are the focus of this paper. More specifically, the subject of analysis is a comparison of the manner in which the right to respect for private and family life is determined (Article 8 of the Convention) and content-wise identical right in the provisions under the respective section on right to privacy (Article 40 of the Constitution of Montenegro) and other essential elements that complement it (Art. 41 - inviolability of the apartment, Art. 42 - secrecy of letters and Art. 43 - personal data). Bearing in mind that the mentioned rights shape the right to privacy as a collective right, they are observed in the paper separately, to the extent that their content and systematics are presented.

In answering this question, normative and comparative law method is primarily used, together with the analysis of cases from court practice.

\section{Right to privacy (term)}

Theoretical considerations on the respect for human integrity and dignity, as primary social and legal values each, preceded the constitutionalization of the right to privacy and its establishment in international legal acts. To this end, "right to one's own world" has been materialized in different ways as it originates from medieval charters on the protection of individuals from the arbitrary actions of state officials. This form will be further shaped in the modern age through affirmation the idea of subjective rights, 
and later by the first written constitution (USA, 1787), more precisely in Amendment 4 from 1791, which set forth: "The right of the people to be secure in their persons, houses, papers, and effects, against unreasonable searches and seizures, shall not be violated, and no warrants shall be issued, but upon probable cause, supported by Oath or affirmation, and particularly describing the place to be searched, and the persons or things to be seized". The interpretation of this provision in accordance with the changed social circumstances, and especially the technical development, has broadened the scope of this right and the procedures for its protection. Along with that, theoretical views on the nature of this right were developed, starting with the traditional theory of the right to privacy heralded in Waren and Brandeis' article The Right to Privacy, published in the Harvard Law Review in 1890s.

The development of industrial society, and subsequently information society would bring about increase in the number of modalities by which the right to privacy could be violated and extended beyond the originally protected violation of the right to home. In that direction, the advancement of information technologies would result in the creation of various databases about individuals, and in the possibility of their abuse. In addition, various dimensions of this right would emerge and acquire the character of a collective right that is broad enough to cover violations of human rights and freedoms that could not otherwise be subsumed under their traditional classification. This is because it consists of several individual rights (right to home, right to secrecy of correspondence and other means of communication, right to protection of personal data etc.) and their number increases in proportion to the efforts to protect the intimacy of individual as effectively as possible.

The framework of this right would get its final shape once it is embedded in the acts of international and domestic law, more specifically, once it is defined as a standard in: 1) international treaties; 2) constitutions and 3) human rights laws and (or) 4) special laws whose subject matter is the right to privacy, as well as numerous bylaws.

The stated features of this right also result in the complexity of its conceptual determination and definition. This generated differences in its content and systematics as found in the acts focused on the subject. This especially refers to the differences that exist between its definition in international treaties and in national law, which is why this paper focuses on the difference in its standardization in the Convention and the Constitution of Montenegro respectively. This relationship is not considered and analysed at scientific, professional or nomotechnical level only, but also in a broader range that determines the scope of protection of this right, and effectiveness of legal remedies used for this purpose.

\section{Relevant provisions on the right to privacy in international law}

Several international documents at universal and regional level contain the right to privacy, under such or similar names.

Article 12 of the Universal Declaration of Human Rights states that: "No one shall be subjected to arbitrary interference with his privacy, family, home or correspondence, nor to attacks upon his honor and reputation. Everyone has the right to the protection of the law against such interference or attacks". 
Article 17 of the International Covenant on Civil and Political Rights prescribes this right in a substantively identical manner, with a difference in legal effect, since the provisions of the Covenant, unlike the Universal Declaration, are binding.

This right is also the subject of the Charter of Fundamental Rights of the European Union in the way that Article 7 stipulates that: "Everyone has the right to respect for his/ her private and family life, home and communications", while Article 8 of the Charter regulates the protection of personal data.

Resolution of the Parliamentary Assembly of the Council of Europe no. 1165 of 1998 broadens the scope of the right to privacy and states that it enables every person "not only to be protected from interference by the authorities, but also from interference by other individuals and institutions, including the media".

\section{Right to respect for private and family life in the Convention and in the Constitution of Montenegro (comparative analysis)}

The basic requirement for any "country in transition" in the implementation of the acquis communautaire is respect for legal values, standards and relevant provisions. However, this does not mean mere replication of legal regulations, but their adaptation to the social context of the member states of the Council of Europe. This is especially true in the field of human rights and as such it is contained in the recommendations for drafting domestic law, especially the Constitution as the highest legal act, and is the most often emphasized in the EU accession process.

Such commitments were declared in relation to Montenegro, ${ }^{1}$ i.e. recommendation was that the human rights enshrined in the Constitution of Montenegro should correspond in content and systematics to those embedded in the Convention. On a quantitative level, this has been fulfilled given that human rights' provisions are stipulated in 63 articles out of 158 articles of the Constitution. However, the question remains if this was achieved in the qualitative (content) level, ${ }^{2}$ and if the names of some human rights and their systematics are fully aligned with the provisions of the Convention. ${ }^{3}$ Such a challenge also arises when analyzing the right to privacy and related rights in the Constitution of Montenegro and their compatibility with the relevant provisions of the Convention.

\footnotetext{
${ }^{1}$ Such a practice existed in the activities, opinions and recommendations of the Commission for Democracy through Law (Venice Commission) in the process of drafting and adopting the current Constitution of Montenegro, such as Opinion of the Venice Commission.

${ }^{2}$ The conceptual and substantive discrepancy between the provisions of the Constitution and the ECtHR has been pointed out by the scientific community and professionals in the process of its drafting and to that end the contributions of M. Šuković and N. Vučinić at the CANU scientific conference on the draft Constitution of Montenegro were published in the collection of papers from this conference from 2007. See: Šuković (ed.), 2007, pp. 28, 63, 64 .

${ }^{3}$ There are several cases in which the names (not normative and essential meaning) of human rights and freedoms from the ECtHR and the Constitution of Montenegro do not match), such as the ECtHR (Article 2) establishes the right to life, while the Constitution of Montenegro prohibits the death penalty (Article 26), the ECtHR (Article 6) establishes the right to a fair trial, while the Constitution of Montenegro contained in several articles (Article 21 - the right to legal aid, Article 35 - presumption of innocence, etc.).
} 
In the European Convention for the Protection of Human Rights and Fundamental Freedoms, this right is enshrined in Article $8,{ }^{4}$ entitled "Right to respect for private and family life". The first paragraph states that "Everyone has the right to respect for his private and family life, his home and his correspondence", while paragraph 2 contains restrictions on this right under which: "There shall be no interference by a public authority with the exercise of this right except such as is in accordance with the law and is necessary in a democratic society in the interests of national security, public safety or the economic wellbeing of the country, for the prevention of disorder or crime, for the protection of health or morals, or for the protection of the rights and freedoms of others".

In the internal legal order of Montenegro, the right to privacy is primarily regulated by the Constitution of Montenegro, 2007, within the framework of personal rights and freedoms, in Article 40, under the rubric of the same name, and is defined by the provision that "Everybody shall have the right to respect for his/her private and family life". In this way, the rubric and the mentioned provision of the Convention do not correspond, since they are not synonyms, given that the term "privacy" has a narrower meaning than the term "private life" established in the Convention, and "refers to all types of intrusions into the private life of an individual" (Beširević et al., 2017, p. 162).

The next three articles of the Constitution are regulated as special rights: inviolability of the apartment (Art. 41), confidentiality of correspondence (Art. 42) and personal data (Art. 43), and at the same time, they are, according to already mentioned opinion, integral parts of the right to private life. Within these three articles, the limitations of certain segments of the right to privacy have been determined, i.e. the conditions under which the guarantees of this right can be waived.

Relevant provisions of the Constitution of Montenegro related to the subject of this paper are the following:

- The provision of Article 9 governing the primacy of international law over domestic law, according to which: "The ratified and published international agreements and generally accepted rules of international law shall make an integral part of the internal legal order, shall have the supremacy over the national legislation and shall be directly applicable when they regulate the relations differently from the internal legislation".

- The provision of Article 16 according to which the law in accordance with the Constitution regulates "the manner of exercise of human rights and liberties, when this is necessary for their exercise".

- The provision of Article 24 which regulates the limitation of human rights and freedoms in such a way that they may be "limited only by the law, within the scope permitted by the Constitution and to such an extent which is necessary to meet the purpose for which the limitation is allowed, in an open and democratic society".

- The provision of Article 28 which determines the protection of the dignity and inviolability of the person, more precisely, the provision of paragraph 2 of this

\footnotetext{
${ }^{4}$ Art. 8 was analyzed in detail in Gutić, 2010.
} 
Article which guarantees the "physical and mental integrity of a man, and privacy and personal rights".

The differences presented in relation to the Convention should not be seen as purely terminological and nomotechnical issues, but as a challenge to the full and effective protection of human rights. This is due to the fact that prima facie it can be noted that the Convention (Article 8) regulates the "right to respect for private and family life" and the Constitution of Montenegro (Article 40) prescribes the "right to privacy" which acquires an essential dimension only if viewed together with the next three articles of the Constitution which determine the inviolability of the apartment, the secrecy of letters and personal data. In this way, the right to privacy, metaphorically speaking, on the example of the Constitution of Montenegro, has the characteristics of a "constitutionally uncodified right".

Therefore, the subject of this paper is the relationship between the cited articles of the Convention and the Constitution of Montenegro and the analysis of their (non) complementarity, as well as of a case in which the ECtHR adjudicated on the open issues pertaining to the relationship thereof.

\subsection{Relationship between Article 8 of the Convention and the segments of privacy rights contained in Articles 40, 41, 42 and 43 of the Constitution of Montenegro}

Art. 8, par. 1 of the Convention guarantees the right to respect for private and family life whose holder is "every citizen", and it consists of four elements, i.e. protected good, and they are: 1) private life, 2) family life, 3) home and 4) correspondence. According to the Convention, all of them have the characteristics of autonomous terms i.e. the ECtHR interprets them in its authentic way, different from what is established in the legal systems of the signatory states

The breadth of the approach in shaping this right stems from the fact that it can be violated in several ways, by endangering various goods, four of which are explicitly mentioned. However, this does not exhaust the list of goods and legal values whose violation means a violation of an individual's privacy, but in practice, their broader interpretation, protects everything that may violate these rights by arbitrary interference by the state and other entities. Theoretical views go in the same direction, according to which the elements of this right include the right to personal identity, i.e. all forms of personal autonomy and those contacts that are maintained in social ties (Popović, 2012, p. 293). This is confirmed in practice by the fact that the provision on private life from Article 8 of the Convention is given a residual character, i.e. it covers factual situations that cannot be supported by other articles of the Convention.

In that sense, the definition from the Convention is more appropriate and comprehensive than the one known in the Constitution of Montenegro, since it does not state two out of the four elements of this right contained in the Convention (respect for home and respect for correspondence) but the constitution creators, as we have already stated classify it as special articles of the Constitution under the titles "inviolability of apartment" (Art. 41) and "confidentiality of correspondence" (Art. 42). 
The disadvantages of such constitutional engineering lie in the fact that the term "apartment" in Article 42 of the Constitution is etymologically narrower than the term "home", just as the term "secrecy of letters" is narrower than the term "correspondence", to the extent that it sounds archaic in the age of modern IT achievements. This observation has not only a legal-technical but also a substantive dimension, because, in one case, it narrows the content of the type of object being protected ("apartment" instead of "home"), and in another, the type of communication by which rights may be violated (violation of secrecy of "letter" instead of secrecy of "correspondence"). This narrows the sphere of privacy that is protected, on both grounds.

The advantage of the wording from the Convention is reflected in the fact that its four constituent elements often overlap in practice, so e.g. violation of privacy subsumes violation of correspondence or violation of personal data. Since such examples of overlap may also apply to the three mentioned articles of the Constitution of Montenegro (Articles 41, 42 and 43) in deciding on the violation of the rights, national judges in each case must weigh "predominance" in the violation of these rights, i.e. certain parts of the same right, as regulated by the Convention. Therefore, in specific cases it is more difficult to determine the relevant law and apply the appropriate norm.

The right to respect for private and family life enshrined in the Convention is not an absolute right, but has precisely stated limitations in its second paragraph. The limitations thereof are set by the provision that public authorities shall not interfere in the exercise of this right unless "it is in accordance with the law and is necessary in a democratic society in the interests of national security, public safety or economic well-being of the country, for the prevention of disorder or crime, for the protection of health or morals, or for protection of the rights and freedoms of others" (art. 8, par. 2).

The reason for such a normative approach is, on the one hand, the confirmation of the rule on narrow interpretation of exceptions, in order to more fully protect the elements of privacy from paragraph 1 . On the other hand, it shows that it is a "qualified convention law", in which public authorities may only interfere under certain conditions. Such rights contain optional restrictions, as the government decides whether to apply them or not. For that reason, they are, as a rule, prescribed by general assumptions and not by the method of enumeration (Maganić, 2016, p. 25).

In domestic law, the mentioned restrictions are not contained in Article 40 of the Constitution, the basic article that regulates this right. They are set out in Articles 41 and 42 of the Constitution, but in such a way that they do not fully follow the content of the restrictions under art. 8, par. 2 of the Convention. For example, the provision of Article 41 which reads "the apartment is inviolable" is by its nature a statement which is not normatively rounded, since the apartment is in practice "vulnerable" and it is therefore to be protected under the right of privacy. There is no provision in the Convention that it [the apartment] may be "vulnerable" under the exceptions set out in Art. 8, par. 2 of the Convention.

\footnotetext{
${ }^{5}$ For more details: Rid, 2007, pp. 407-410.
} 
Instead, Art. 41 sets out guarantees of the inviolability of the apartment relating to the conditions under which a search may be conducted without the consent of the holder, while Art. 42 sets out derogations from the inviolability of the secrecy of letters, telephone conversations and other means of communication. Limitations are also established indirectly in Art. 43 by establishing a ban on the use of personal data beyond the purpose for which they were collected.

This normative approach does not directly respect the standards from Art. 8 of the Convention, but they are divided into several constitutional provisions related to the right to privacy. In such a situation, restrictions for arbitrary interference with the right to privacy are found in the provision of Art. 24 of the Constitution, which is placed within the common provisions on human rights. However, the provision of Art. 24 of the Constitution does not fully cover the limitations set out in Art. 8, par. 2 of the Convention because the Convention explicitly refers to the prohibition according to which public authorities cannot interfere with the exercise of the right to respect for private and family life, while in the abovementioned article of the Constitution it is done in a general way and refers to all human rights.

Furthermore, the Convention states the reasons for derogations from the violation of the right to respect for private and family life (interest of national security, public safety and economic well-being of the country, prevention of disorder or crime, protection of health or morals, protection of rights and freedoms of others). They are in accordance with the law and are necessary in a democratic society. The term "in accordance with the law" includes other acts that are not essentially law (bylaws), as well as case law and standards from the Convention, and finally the quality of legislation in accordance with European standards. The term "necessary" implies that interference in private and family life can be achieved if there is a proportional connection with the legitimate aim. All this is not contained in the Constitution, and the mentioned sub-regulation can, in practice, among other things, be conducive to the non-implementation of the proportionality test.

The presented normative inconsistency may result not only in inconsistency of jurisprudence and inefficiency in the protection of this right, but, ultimately, in violation of the (conventional and constitutional) right to a trial within a reasonable time.

For these reasons, we will analyze the scope of domestic constitutional solutions, their impact on respect for the privacy of individuals, as well as the adequacy of the resulting legal reasoning, using the case law of the European Court of Human Rights in the application of Article 8 of the Convention to Montenegro.

\subsection{The case law of the ECtHR in relation to Montenegro in application of Article 8 of the Convention (Antović and Mirković v Montenegro)}

The stated ambiguity of the constitutional text in the part related to the right to privacy can be partly seen in the procedure and decision in the case of Antović and Mirković v Montenegro, as well as in the judgment of the Basic Court and Higher Court in Podgorica that preceded it. 
The judgment in the present case concerns the determination of whether the unlawful installation of video surveillance violated the right to respect for private life under Art. 8 of the Convention. Namely, the applicants (university professors) alleged a violation of their right to respect for private life, which was violated by placing video surveillance in teaching amphitheaters, which endangered their integrity and dignity. The management of the Faculty and the University disputed that respectively, stating that it was done in order to secure property and persons.

Acting on the lawsuit of the mentioned persons, the Basic Court in Podgorica (Application No. 180/12 from 27 December 2012) rejected the lawsuit for damages on the grounds the violation of the right to respect for private life against the University of Montenegro, the Agency for Personal Data Protection and the state of Montenegro. This is explained by the fact that the University is an institution of public interest, that its activities are conducted publicly, that the work of a university professor is open to public, and that individual rights cannot be violated in the described manner (installation and use of video surveillance). The High Court in Podgorica upheld the cited decision, stating that the decision of Basic Court was provided with a "sufficiently related the ECtHR's case-law to the case at issue" and found that the applicant's allegations "did not justify ruling otherwise in the present case" (Judgment Gž. No. 882/13 from 17 July 2013). ECHR case-law was cited in general manner, without describing the relationship between cases in detail. ${ }^{6}$

Acting on the applicants' application, the ECtHR cited the relevant articles of domestic law and noted that the articles of the Constitution cited differed from those cited in other judgments of Montenegrin courts relating to Art. 8 of the Convention. ${ }^{7}$ This is the testimony to the fact that the constitutional inconsistency in shaping the right to privacy leads to their different evaluation and "weighing" when interpreting the disputed relationship, both in international and national law. It also makes it harder to determine the "margin of appreciation" or to have it invoked by the Government before the ECtHR, or to determine positive obligations for the state, as in the case in Mijušković $v$ Montenegro. It has an effect on the absence of a proportionality test in those cases where there is interference with private life, which should be justified by the notion of "necessity in a democratic society".

In the case of Antović and Mirković v Montenegro, the Court also made reference to the principles developed through the ECtHR's case law, and the Court emphasized the broad scope of the term "private life" which cannot be reduced to the term "inner circle" in which an individual can live his personal life how he chooses and excludes from it the whole outside world not included in that circle. In contrast, the national court did not treat the lecture halls as a space where the right to privacy could be violated, which in this case intersects in a broader context with the right to inviolability of the home.

The one-sided approach and rigidity in the application of law in this case is reflected in the fact that neither Basic Court nor the High Court considered the compliance of

\footnotetext{
${ }^{6}$ For more details about citing desicions in this manner: Cozzi et al, 2016, pp. 99-102.

${ }^{7}$ Various constitutional grounds are found in other judgments challenged before the ECtHR, such as Mijušković $v$ Montenegro, Milićević v Montenegro, Drašković v Montenegro.
} 
the actions of the "educational authorities" (Universities and faculty) with the Law on Personal Data Protection which in the general provisions, among other things, stipulates that "personal data may not be processed to an extent greater than necessary to achieve the purpose of processing or in a manner inconsistent with their purpose" (art. 2, par. 2 of the Law). Thus, the provision of art. 8, par. 2 of the Convention that respect for "private life" and "home" can be limited only "in accordance with the law" was not respected as a relevant right.

Also, the opinion of the Council of the Agency for Personal Data Protection of 28 April 2011 was not taken into account either, as the Council stated in its decision that the conditions for the introduction of video surveillance provided by law were not met, primarily because there was neither evidence of danger to safety of people and property in amphitheaters, nor to confidential information. Based on that, the Council stated that video surveillance of lectures was not a legitimate basis for installing equipment in that direction, invoking the provisions of art. 35-40 of the Law. ${ }^{8}$ An analysis of this and other privacy cases shows that national courts did not focus at all or did not sufficiently focus on the proportionality test.

The distinction between the "right to privacy" and the "right to private life" in the way that these are two rights, and not a relationship between a part and a whole, is also in favor of constitutional sub-regulation. Based on such normative inconsistency, the decision of the Basic Court established that the right to privacy is related to the "strictly private and intimate sphere of life as the right of everyone to live their own life", while the "right to private life" is qualified as a restrictive right "to the extent that the individual himself brings his private life into contact with public life". However, this is one of the principles of interpretation of the Convention in relation to this article, because "the right to privacy" implies a more restrictive approach and field of action that limits the traditional notion of privacy, while "private life" has a very broad meaning and is more similar to the notion of personal autonomy.

Based on that, it was concluded that in the amphitheater, "the professor does not perform any private work, nor can he at any time feel the privacy in that capacity, which could be violated in connection with the performance of work duties". Thus, the violation of private life is related to the nature of work (work engagement or private work), which is a feature of narrow interpretation that is not inherent in the modern concept of application of human rights provisions. In contrast, the ECtHR in the case of Nemec $v$ Germany concluded that "there is no sufficient reason to exclude professional or business activities from the concept of private life". 9

In addition to considering Art. 8 of the Convention and constitutional provisions directly related to the right to privacy (Art. 40, 41, 42, and 43), the lack of direct application of Art. 9 of the Constitution, which determines the primacy of international law over domestic law, should be pointed out. Recognizing the fact that the Convention establishes derogations from privacy in a more complete and at the same time different way, there was

\footnotetext{
${ }^{8}$ For more information: Braithwaite, Harby \& Miletić, 2017, p. 27.

${ }^{9}$ For more details: Krstić \& Marinković, 2016, p. 170.
} 
room for the Basic and Higher Courts to directly apply art. 8, par. 2 of the Convention, as was done in the jurisprudence of the Supreme Court of Cassation of Serbia (Supreme Court of Serbia, No. 336/2017 from 25 January 2018).

All of the above may be a consequence of constitutional inconsistency in the formulation of this right and combined with insufficient application of ECtHR's case law it may affect the quality of human rights protection in internal legal order. In support of (non)application of the ECtHR's case law goes the fact that the decision of the Basic Court incompletely and superficially cites its [ECtHR's] case law, without quoting the name and reference number of the cases in which the ECtHR ruled.

\section{Concluding remarks}

Content of the paper and analysis of the topic proved that the selected topic does not include only nomotechnical level. Contrary to that, this topic includes and has impact on wider legal phenomena, especially protection of the human rights and effectiveness of legal remedies used for that purpose.

Starting from the complexity and challenge that the process of implementation of international law into domestic law opens, especially in the part related to human rights and the application of the Convention, it is necessary to take normative and other measures to enable full realization of the right to privacy.

More specifically, in order to expand the scope of the right to privacy, it is necessary to:

- propose a revision of the provisions of the Constitution of Montenegro, in the part related to the right to privacy, in a way that merge those articles of the Constitution $(40,41,42$ and 43$)$, which individually regulate certain segments of this right. In the new constitutional solutions, the name and constituent elements of this right should be consistently aligned with the provisions of art. 8 of the Convention, namely stipulate right to respect for private and family life protecting: private life, family life, correspondence and home. Having in mind the complexity and duration of the procedure of constitutional changes, it is necessary, until the adoption of new solutions, to fully apply the case law of the ECtHR in relation to the protection of this right, as well as to draft legal positions of the Supreme Court that would facilitate the process of law enforcement;

- in accordance with art. 8, par. 2 of the Convention, to supplement and specify the grounds for restricting this right in order to avoid arbitrary interference of the state in its exercise and any action that is not "in accordance with the law" and not "necessary in a democratic society";

- to intensify the activities of institutions and organizations that, besides the courts, employ various activities to promote and protect numerous segments of right to privacy (Protector of Human Rights and Freedoms, Montenegro's Representative before the ECtHR, Parliamentary Committee on Human Rights, NGOs, professional associations of lawyers, etc.); 
- undertake activities so that in the teaching process (law faculties), at professional conferences, as well as in the initial and continuous training delivered by the Center for Education of Personnel in the Judiciary and State Prosecutor's Office, this topic is represented in proportion to its importance. To this end, it is necessary to conduct multidisciplinary research in order to consider all aspects of the right to privacy, especially those that are the product of new dimensions of IT development.

\section{References}

Beširević, V. et al. 2017. Komentar Konvencije za zaštitu ljudskih prava i osnovnih sloboda. Službeni glasnik: Beograd.

Bobio, N. 2008. The Age of Rights - twelve essays on human rights. Belgrade.

Cozzi, A. et al. 2016. Comparative review of the implementation of European Court for Human Rights. Council of Europe: Belgrade.

De Vergottini, G. 2015. Uporedno ustavno pravo. Translated by Ljiljana Grubač. Službeni glasnik: Beograd.

Gutić, S. 2010. Pravo na privatnost u Evropskoj konvenciji za zaštitu ljudskih prava i osnovnih sloboda. Strani pravni život, 54(2), pp. 335-346. Available at: http://www. stranipravnizivot.rs/index.php/SPZ/article/view/578.

Krstić, I. \& Marinković, T. 2016. Evropsko pravo ljudskih prava. Beograd: Savet Evrope. Maganić, A. 2016. Praksa Evropskog suda za ljudska prava i pravo na dom. In: Barbić, J. (ed), Pravo na dom. Zagreb: Hrvatska akademija znanosti i umjetnosti, pp. 19-54. Popović, D. 2012. Evropsko pravo ljudskih prava. Beograd.

Rid, K. 2007. Evropska konvencija o ljudskim pravima (vodič za praktičare), knjiga 2. Beograd. Šuković, M (ed.). 2007. Prilog javnoj raspravi o nacrtu Ustava Crne Gore. Podgorica: Crnogorska akademija nauka i umjetnosti.

\section{Legal sources}

Charter of Fundamental Rights of the European Union, OJ C 326, 26.10.2012, p. 391-407. Constitution of Montenegro, Official Gazette of Montenegro, No. 1/07.

Convention for the Protection of Human Rights and Fundamental Freedoms, Rome, 4.XI.1950. Available at: https://www.echr.coe.int/Documents/Convention_ENG.pdf. Council of Europe, Parliamentary Assembly. Resolution of the Parliamentary Assembly of the Council of Europe no. 1165 of 1998.

International Covenant on Civil and Political Rights, Adopted and opened for signature, ratification and accession by General Assembly resolution 2200A (XXI) of 16 December 1966 entry into force 23 March 1976, in accordance with Article 49.

Law on Personal Data Protection, Official Gazette of Montenegro, No. 79/08, 70/09 and 44/12. Opinion of the Council of the Agency for Personal Data Protection of 28 April 2011.

UN General Assembly, Universal Declaration of Human Rights, 10 December 1948, 217 A (III). Available at: https://www.refworld.org/docid/3ae6b3712c.html. 


\title{
Website references
}

Opinion of the Venice Commission CDL-AD (2007) 047 adopted at its 73rd plenary session (Venice, 14-15 December 2007). Available at: https://www.venice.coe.int/ webforms/documents/?pdf=CDL-AD(2007)047-e.

Braithwaite, B., Harby, C. \& Miletić, G. (eds). 2017. Freedom of expression and its relationship with the right to respect for private life and the right to a fair trial (case law of the European Court of Human Rights). Tirana: The AIRE Centre and Civil rights defenders. Available at: https://rolplatform.org/wp-content/uploads/2018/03/ free_expression_guide-eng.pdf, (11.11.2020).

\section{Case law}

ECtHR, Antović and Mirković v Montenegro, application No. 70838/13, Judgment 28 November 2017.

ECtHR, Mijušković v Montenegro, application no. 49337/07 of 21 September 2010.

ECtHR, Milićević v Montenegro, application no. 2781/16 of 6 November 2018.

ECtHR, Drašković v Montenegro, application no. 40597/17 of 9 June 2020.

ECtHR, Niemietz v. Federal Republic of Germany, application no13710/88 of 16 December 1992. Supreme Court of Serbia, No. 336/2017 from 25 January 2018.

Basic Court in Podgorica (Montenegro), Application No. 180/12 from 27 December 2012. High Court in Podgorica (Montenegro), Judgment Gž. No. 882/13 from 17 July 2013.

\section{Ivan M. Vukčević, MLS}

Programski direktor Centra za monitoring i istraživanje (CeMI), Podgorica, Crna Gora e-mail:ivan.vukcevic@yahoo.com

\section{ČLAN 8 KONVENCIJE O ZAŠTITI LJUDSKIH PRAVA I OSNOVNIH SLOBODA I PRAVO PRIVATNOSTI U USTAVU CRNE GORE}

\author{
Sažetak
}

Predmet rada je uporedna analiza prava na poštovanje privatnog i porodičnog života u Evropskoj konvenciji za zaštitu ljudskih prava i osnovnih sloboda i prava na privatnost sadržanog u Ustavu Crne Gore. U tom cilju vrši se prezentacija relevantnih odredbi u ovim dokumentima, uz kritički pristup njihovoj (ne)usaglašenosti, kako u određenju konkretnih prava, tako i slučajevima njihovih ograničenja. Rad treba da ponudi odgovor na pitanje - da li je u Ustavu Crne Gore na primjeren način implementirano ovo pravo, kao i da li njegov drugačiji sadržaj, na konkretnom primjeru, zahtijeva neposrednu primjenu 
normi međunarodnog prava. Istovremeno, cilj autora je da pruži saznanja da li nedovoljna usklađenost odredaba međunarodnog i nacionalnog prava na ovom planu može uticati na potpuniju zaštitu ovog prava. $\mathrm{U}$ tom cilju u radu je analiziran jedan od predmeta $u$ kojima je Evropski sud za ljudska prava odlučivao o povredi člana 8 Evropske konvencije o zaštiti ljudskih prava i osnovnih sloboda u odnosu na Crnu Goru. Polazeći od izložene materije, na kraju rada, izvedeni su odgovarajući zaključci o mogućim pravcima dogradnje postojećih rješenja i prakse u kojoj se ona ostvaruju. U radu su korišćeni normativni i komparativni metod, zajedno sa analizom sudske prakse.

Ključne riječi: pravo na privatnost, Konvencija za zaštitu ljudskih prava i osnovnih sloboda, Ustav Crne Gore, sudska praksa.

Article history:

Received: 11 November 2020

Revised: 7 December 2020

Accepted: 20 January 2021 